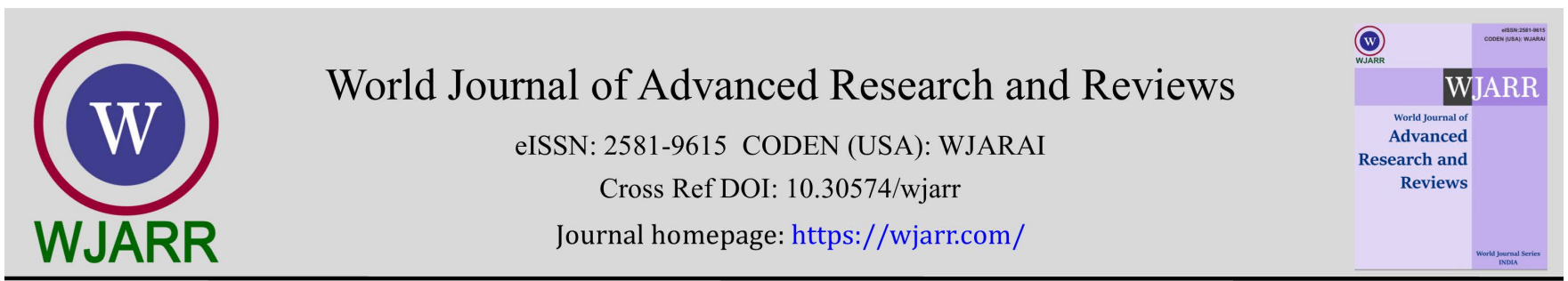

(RESEARCH ARTiClE)

\title{
Perception of the cost benefit ratio of the stone crushing activity by actors in the informal sector of the Collines Department in Benin
}

\author{
Félicien Tossou 1, Rodrigue Codjo Landeou ${ }^{3,}{ }^{*}$, Ibouraïma Yabi ${ }^{2}$ and Michel Boko 4 \\ ${ }^{1}$ Inter-faculty Center for Environmental Training and Research for Sustainable Development at the University of Abomey- \\ Calavi (CIFRED / UAC). \\ ${ }^{2}$ Laboratory for the Study of Urban Dynamics of the University of Abomey-Calavi. \\ ${ }^{3}$ Faculty of Human and Social Sciences of the University of Abomey-Calavi (FASHS / UAC). \\ ${ }^{4}$ Pierre Pagney Laboratory of Climatology of the University of Abomey-Calavi..
}

World Journal of Advanced Research and Reviews, 2021, 11(03), 316-326

Publication history: Received on 23 July; revised on 23 September 2021; accepted on 25 September 2021

Article DOI: https://doi.org/10.30574/wjarr.2021.11.3.0344

\begin{abstract}
Artisanal stone crushing is one of the income-generating activities practiced by many populations of the Collines Department in the Republic of Benin. It is a dangerous activity in which the actors ignore the occupational risks. This research was initiated to study the working conditions of crushing operators in the Collines Department, in order to assess the associated occupational risks. The methodological approach adopted to achieve these objectives consists of documentary research, surveys and field interviews with questionnaires, interview guides and direct field observation based on an observation grid. The data were collected from 64 artisanal stone crushers aged over 15 years 12 men and 52 women, ie a sex ratio of 4.3 in favor of women. The study was carried out at 5 sites in three Communes of the Collines Department. The data were processed with SPSS 21 software. The results obtained showed that the median age of the actors is 44 years with a minimum of 18 years and a maximum of 71 years. One in two people have not set foot in school. The average seniority in crushing is 16 years. The work provides less than 10,000f per month for three people out of 5 . The daily working time varies from 5 to 12 hours. The majority work 6 days a week (84.4\%). The complaints made by those involved in crushing are: heartache (59.4\%), low back pain and back pain (12.3\%), followed by accidents (9.4\%) and respiratory ailments (9.4\%). For $4 / 5$, certain times of the year would be more at risk and for $45.3 \%$, it is the rainy season. More than $77 \%$ of people recognize that there are specific risks to children, including the risk of accidents. For prevention, the majority of women wear pants to protect their private parts. Wearing shoes is not systematic. No one wears protective equipment for their hands, eyesight, hearing, or airways.
\end{abstract}

Keywords: Perception; Stone crushing activity; Informal sector; Collines Department in Benin

\section{Introduction}

Mines account for a significant share of the gross domestic product (GDP) of many developing countries and often even constitute the bulk of exports and foreign investment in these countries [1]. Artisanal type mining operations have been practiced in West Africa since the earliest times [2]. Thus, the building materials, the exploitation of which began with the first constructions of human habitat, have, throughout history, formed the basis of the wealth and / or power of many empires and kingdoms of the sub-region [2]. This is the case, among others, of Benin and particularly of the Collines Department which supplies most businesses and households with gravel for the construction of infrastructure.

\footnotetext{
${ }^{*}$ Corresponding author: Félicien Tossou

Inter-faculty Center for Environmental Training and Research for Sustainable Development at the University of Abomey-Calavi (CIFRED / UAC).
} 
Despite employing only $1 \%$ of the global workforce, the mining industry is responsible for around $8 \%$ of fatal work accidents (around 15,000 per year) [1]. There are no reliable statistics on the number of injured, but it is high, as are the number of cases of diseases directly related to work in mines such as stone crushing quarries (pneumoconiosis, hearing loss, vibration-induced disorders) that lead to early disability or even death. All day long, women and children hammer large blocks of stone and granite rock into pebbles, exposing themselves to inhalation of granite dust and other crystalline dust [3]. However, rock dust consists of fine particles of $5 \mu \mathrm{m}$ which reach the bronchi and the smallest alveoli [4].. These are nanoparticles whose knowledge of physicochemical parameters allows us to better understand their behavior in biological media and their mechanism of internalization in cells. Nanoparticles are found in the lungs causing pneumoconiosis and in DNA through their genotoxicity [5].

In the Department of Hills, small-scale stone crushing quarries are an important source of employment. Often overlooked in some countries, they employ many more workers than the recognized mining industry [6]. But these activities are carried out under very difficult conditions where safety and health rules are not respected. Hence the need to study the occupational risks associated with artisanal stone crushing work and their prevention in the informal sector of the Collines department in Benin.

\section{Material framework and methods of study methods}

\subsection{Study framework}

The Collines department (figure 1) is located in the central part of the Republic of Benin, between $7^{\circ} 30^{\prime \prime}$ and $8{ }^{\circ} 50 "$ north latitude and between $1^{\circ} 30^{\prime \prime}$ and $2^{\circ} 50^{\prime \prime}$ east longitude. It occupies an area of $13,931 \mathrm{~km} 2$ and shares its borders with the departments of Zou to the south, the departments of Borgou and Donga to the north and the Republics of Togo to the west and Nigeria to the east. Administratively, it is subdivided into 6 Communes namely: Bantè, Dassa, Glazoué, Ouessè, Savalou and Savè. These 6 municipalities are organized into three (3) health zones, according to the national health pyramid: SABA, DAGLA and SAO.

From a climatic point of view, the Collines department is in a transition zone and is subject to the influences of the subequatorial climate of the south and the humid tropical climate of the north. The dry season lasts from mid-October to March, or 5 months, compared to 7 months for the rainy season (April to mid-October). The temperatures are characterized by strong heat in the middle of the day $\left(36^{\circ} \mathrm{C}\right)$, and marked freshness at night and in the early hours of the day: around $21^{\circ} \mathrm{C}$ (ASECNA, 2019). The harmattan goes through a much longer and harsher phase in January and sometimes in early February. The monthly average temperatures vary between $27^{\circ} \mathrm{C}$ and $31^{\circ} \mathrm{C}$. The months of February to April are the hottest months and the months of July to September are the least hot months).

The geomorphological context of the environment corresponds to a granite-genosic peneplain with the presence of hills (altitudes of 200 to $400 \mathrm{~m}$, even beyond). It is an old flattening surface of granitic and gneissic rocks on which the Topographic substratum is interspersed with residual forms of relief (hills, inselbergs). The numerous inselbergs in this region show the bedrock, with marked curves giving steep slopes. It is thus an environment of great availability of stones, object of artisanal crushing. Indeed, the rocks in place have undergone a strong alteration causing many screes to be disposed of which constitute the material to be crushed. Also, the fragility in places of the rocks means that they do not withstand the temperature of the fires used for their bursting.

The population of the department, estimated at 828,309 inhabitants in 2018 (RGHP 2014), is dominated by the Nago $(46.2 \%)$ and the Fon and related (38.5\%). It is predominantly agricultural [7]. But more and more, this population is engaged in artisanal stone crushing. 


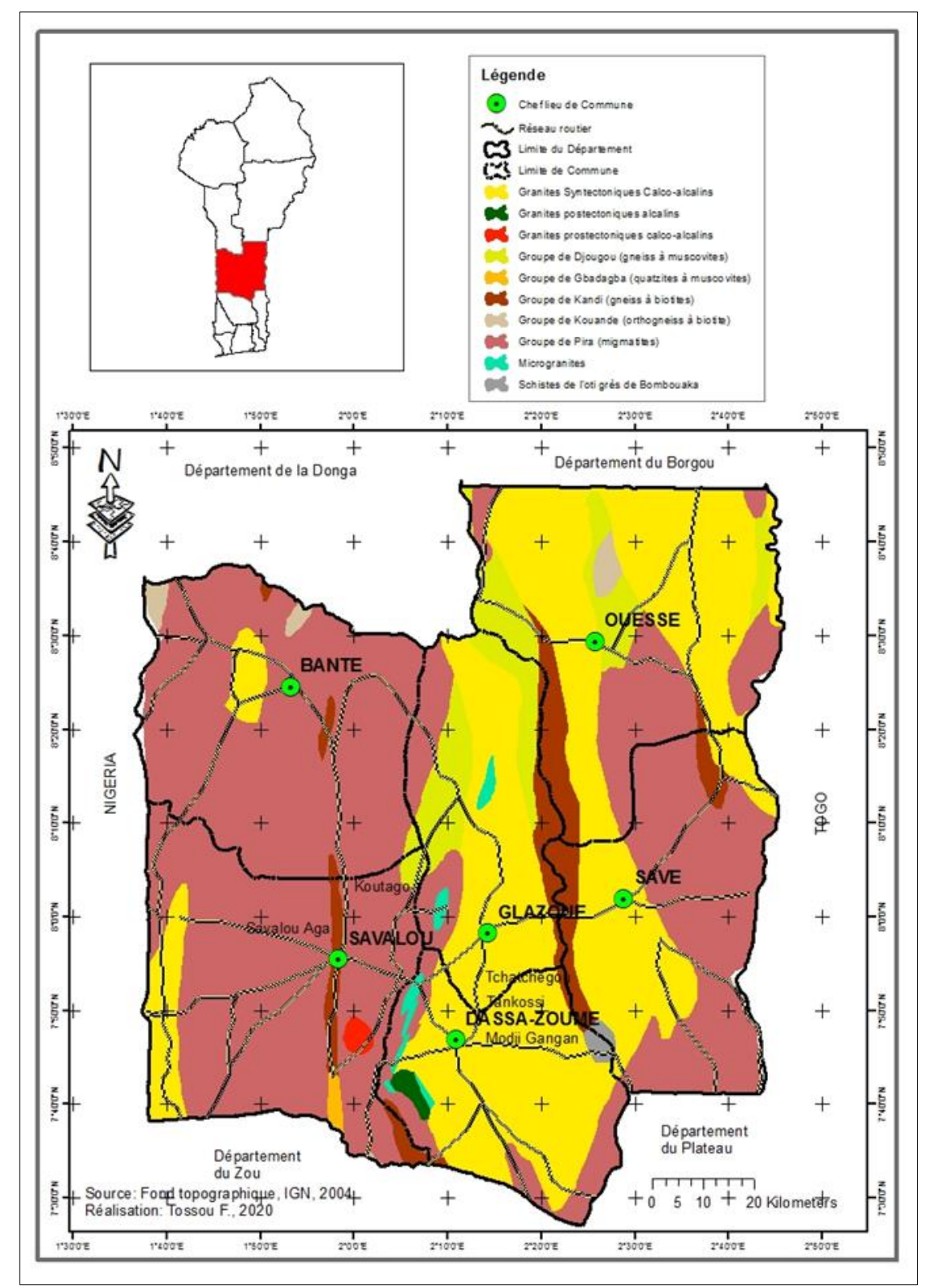

Figure 1 Geological characteristics of the Collines department

\section{Data collection and processing methods}

\subsection{Data collection tools}

In the context of this research, several tools and materials were used. The information was obtained using questionnaires, interview guides and an observation grid. A camera took pictures which served to illustrate the work.

The data was collected in two stages: an exploratory phase and an in-depth investigation phase. During the exploratory phase, the entire department was visited, which made it possible to identify the districts that are engaged in the activity. Contacts have been made with the operators.

The in-depth investigation phase made it possible to identify the operators by district, to interview them and to get to know the working methods and tools at the site level. This made it possible to better study the occupational risks associated with the artisanal stone crushing activity in the Collines department. 
The sample size was obtained by the homogeneous exposure group (GHE) technique. The statistical units were determined by no sampling on the lists of names of groups of craftsmen. In total, the study involved 64 subjects over the age of 15, 12 men and 52 women (Table 1) [8]. The exclusion criteria were those under 15 and absent.

Table 1 Breakdown by site of the subjects taken into account

\begin{tabular}{|l|c|c|c|c|c|}
\hline $\begin{array}{l}\text { Municipalities retained in the } \\
\text { department }\end{array}$ & \multicolumn{2}{|c|}{ Glazoué } & \multicolumn{2}{c|}{$\begin{array}{c}\text { Dassa- } \\
\text { Zoumé }\end{array}$} & \multicolumn{2}{c|}{ Savalou } \\
\hline Sites selected at municipal level & Tankossi & Tchatchégou & $\begin{array}{c}\text { Modji } \\
\text { Gangan }\end{array}$ & Koutaago & $\begin{array}{c}\text { Savalou } \\
\text { Aga }\end{array}$ \\
\hline $\begin{array}{l}\text { Workforce (N) of crushers per site } \\
\text { (according to existing list) }\end{array}$ & 76 & 90 & 31 & 114 & 42 \\
\hline $\begin{array}{l}\text { Size (n0) of the sample drawn per site } \\
\text { (according to GHE) }\end{array}$ & 14 & 14 & 11 & 11 & 11 \\
\hline Study sample size (n) & & 64 & & \\
\hline
\end{tabular}

\subsection{Data processing}

The data collected were introduced into the SPSS 21 software for their analysis and the calculation of some averages, then the Excel 2013 software was used to transform certain tables into graphs.

\section{Results and discussion}

\subsection{Sociodemographic characteristics of stone crushing actors in the Department of Hills}

The results showed a female predominance in the manual crushing of granite rocks in the Colline Department, with a sex ratio of 4.3 women for one man. The manual rock crushing population is relatively young with a mean age $43.2 \pm$ 10.9 years. The early-exposed population is made up of not highly educated as shown in Figure 2.

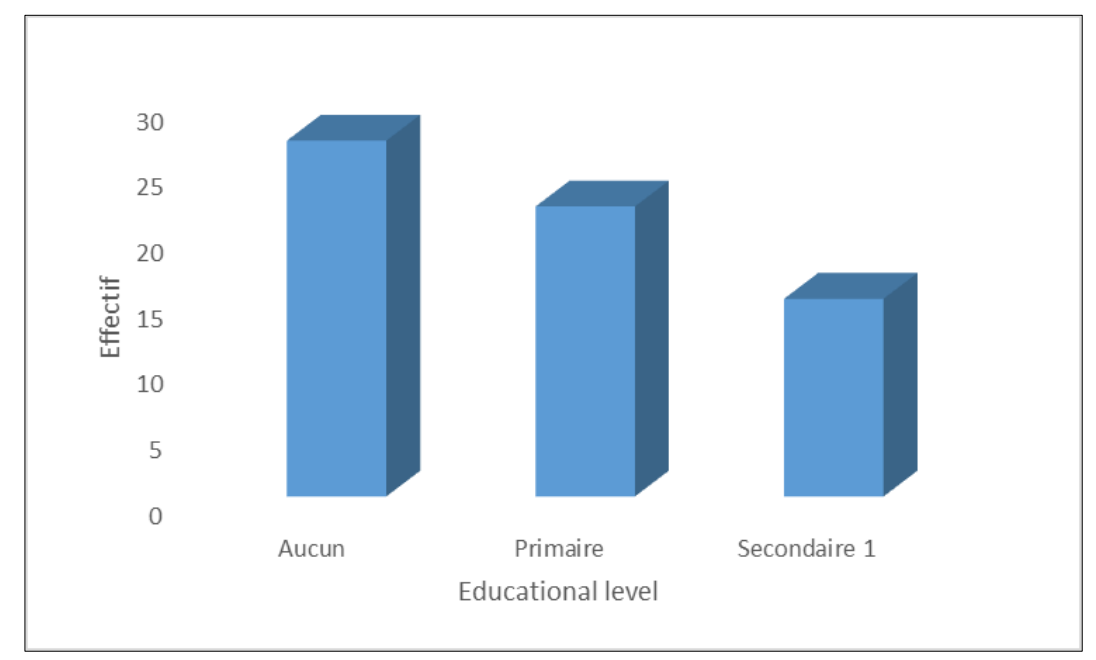

Figure 2 Distribution of artisanal stone crushers surveyed according to their level of education; (Source: Fieldwork, Tossou F., 2021)

As shown in Figure 2, the highest level of education of the crushers surveyed is lower secondary education. This level is reached by only $23.4 \%$ of the people surveyed. The remainder is made up of $42.2 \%$ of illiterates who have no education level and $34.4 \%$ of primary level.

Most crushers have 10-19 years of experience in artisanal crushing with an average of 16.23 years in business. The oldest has been working for 36 years and the least experienced has been working for 1 year. 
The responding actors work more than 8 hours of work per day and work 6 days of work per week (figure 3).

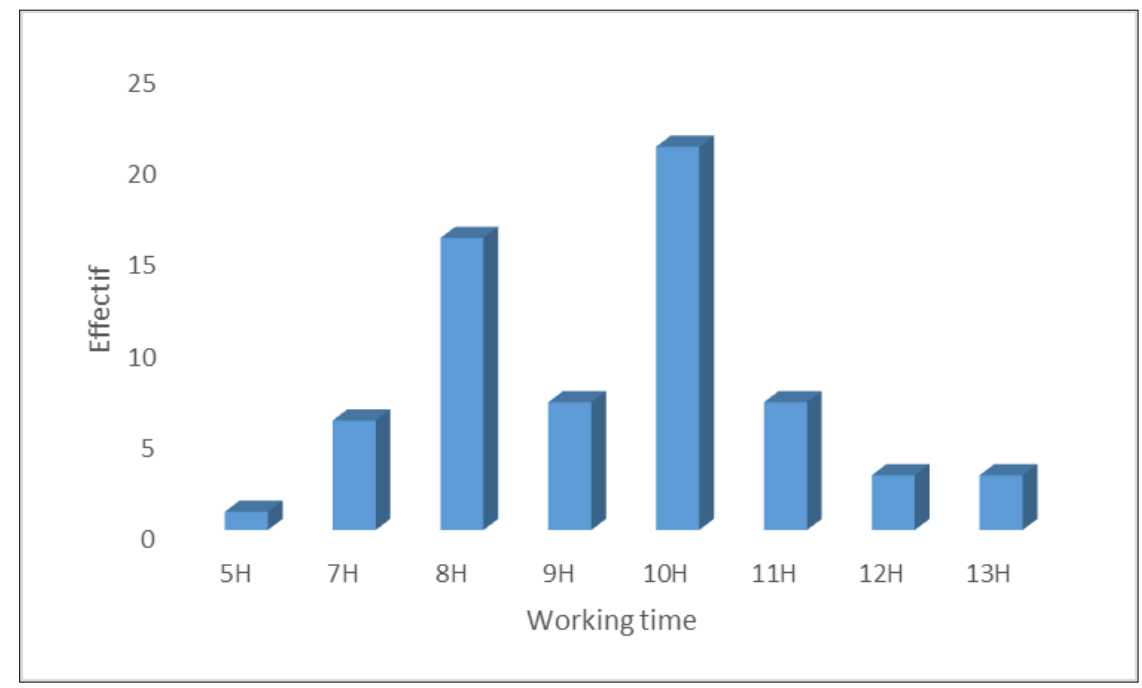

Figure 3 Breakdown of crushers according to working time per day; (Source: Fieldwork, Tossou F, 2021)

Only $36 \%$ of the populations who engage in this activity work at most 8 hours a day. This work overload can be the basis of many microtraumas, precursors of more serious pathologies such as musculoskeletal disorders (MSDs) of the upper limbs or accidents. We find repetitive movements and intense physical efforts due to the weight of the hand tools used (up to $20 \mathrm{~kg}$ ). The majority (85.9\%) of these populations work 6 days a week and only enjoy a weekly rest day.

\subsection{Characterization of the activity}

In the informal sector, the stages of the process are also numerous with difficulties and risks at all levels:

- $\quad$ taking the bedrock from a large wood fire on the hill (pyro-diaclasage) (figure 4),

- fragmentation in 2 or 3 phases, reduction into gravel of different sizes,

- $\quad$ loading and transport.

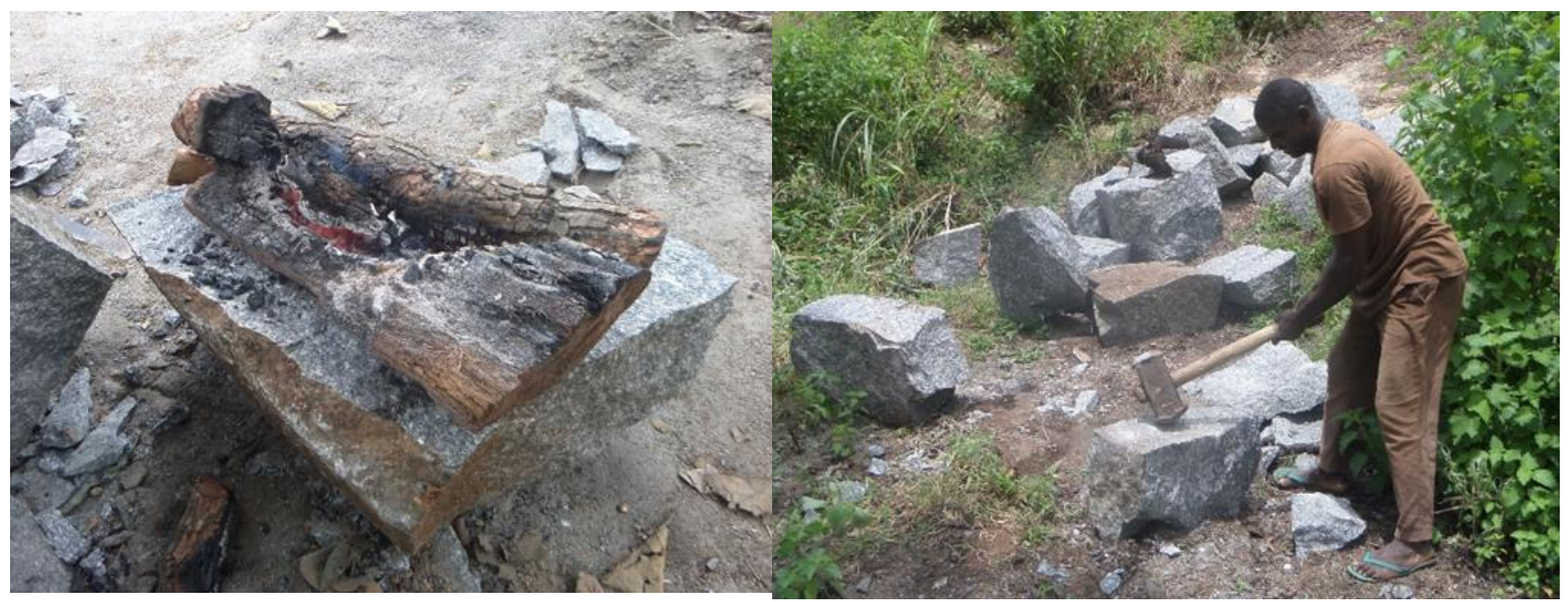

Photo1 a Pyro-diaclasage operation

Photo1 b Stripping operation

Figure 4 Pyro-diaclasage operation followed by stripping at artisanal crushers in the Municipality of Dassa-Zoumé; Shooting: Tossou F. August 2019

As shown in photo a of figure 4, the massiers made up mostly of men from the crushing industry set fire to the hill caves with firewood to create cracks in the rock (pyro-diaclasage). After cooling, they proceed to stripping through the cracks created, using a mass hammer (photo b). After this stripping step, follows the fragmentation and transport of the stone blocks. Using sledgehammers, the sledgehammers reduce the size of the stone blocks to facilitate their transport. The 
women and children then take charge of transporting the stone blocks to the crushing sites. Transport is done in basins if the blocks are small and without containers if the blocks are medium. They travel hundreds of meters under their burdens before reaching crushing sites, which are often near interstate roads. Once there, they brutally overturn the blocks and so starts another phase which is crushing as shown in figure 5.
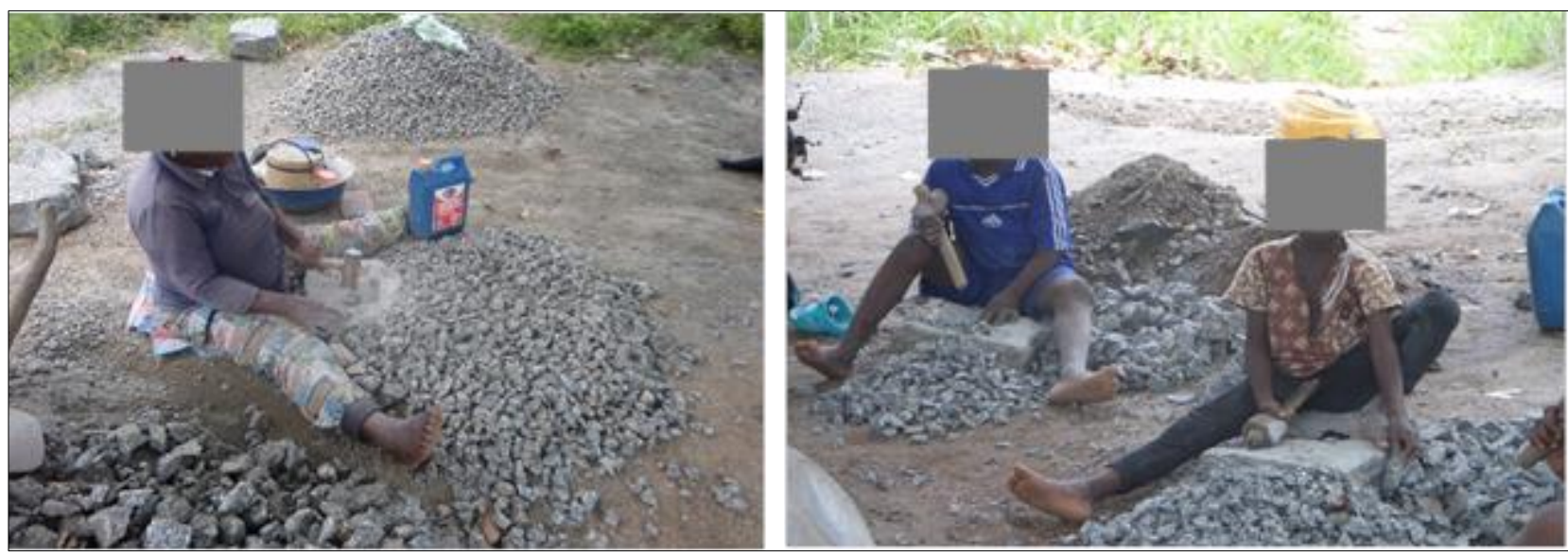

Figure 5 Woman and children in full crushing activity in the Municipality of Savalou; Shooting: Tossou F. August 2019

Women and children use the small hammers to crush the blocks until the gravel is obtained. The work is done essentially under the sun, in the same position throughout the day with the movements of hammers which produce a deafening din. While the dominant posture among massiers is standing leaning forward, that of crushers is sitting with legs apart. The work requires a lot of physical effort, especially for massiers. Children are ubiquitous despite the existence of messages banning child labor. They come from all age groups and accompany their mothers or participate in labor. They have suitable tools but it is not uncommon to find some that use the tools of adults.

\subsection{Work tools}

The tools used by those involved in crushing are manual, consisting mainly of hammers of different sizes, but also large iron bars sometimes exceeding two meters in length (heavy and exceeding $2 \mathrm{~m}$ ), shovels, hoes, cutters, large diameter metal hoops and used tires (figure 6). Pieces of stone serve as a seat and an anvil.

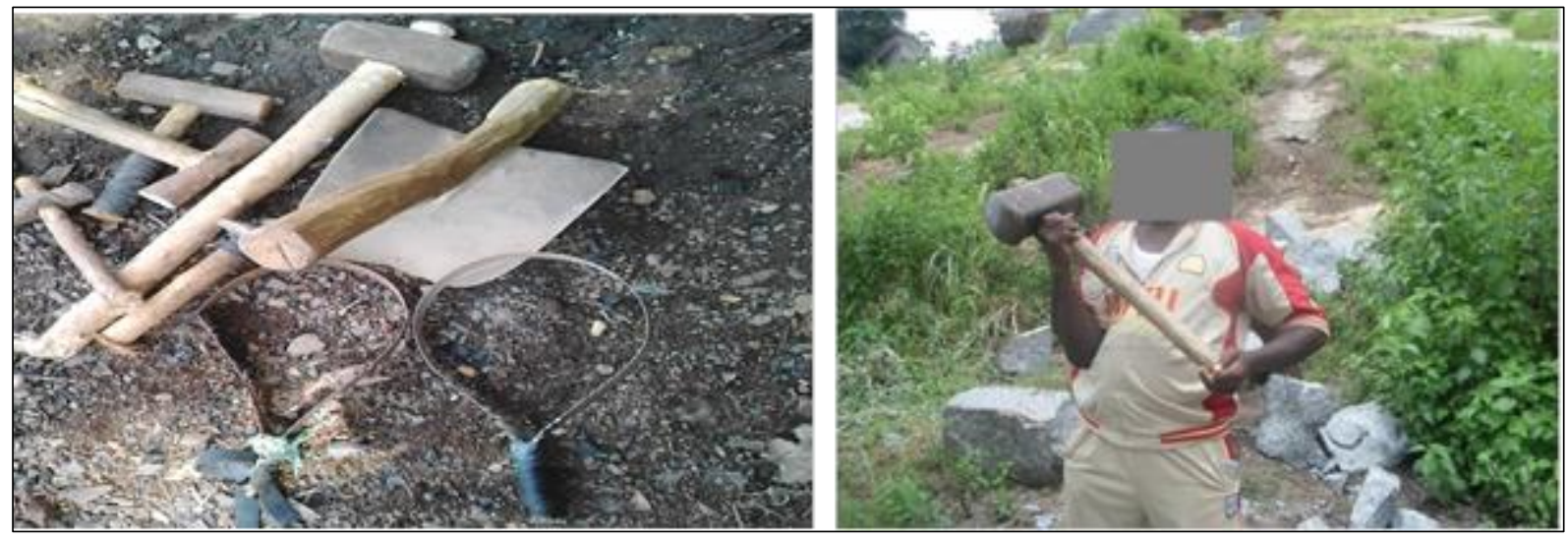

Figure 6 Hand tools used by artisanal crushers; Shooting: TOSSOU F., 2020

\subsection{Economic contribution of the activity}

The artisanal stone crushing activity provides income to stakeholders in the sector. It has become the main activity of some people and generates them a significant daily income. For an estimate of the income, the case of a typical crusher was taken: a young lady between the ages of 30 and 40, in good physical and mental health. It produces an average of 15 barrels of gravel per week, working 6 days a week. The barrel sells for 4,000f CFA, it makes about 60,000 f CFA per week of work. She buys the load of a tricycle at 3,000f, provides transport for 1,500f, pays $2,500 \mathrm{f}$ to the secondary 
massiers and 2,500f to the crusher helper to produce an average of 12 barrels from this load. She thus spends 3,000+ $1,500+2,500+2,500$ (or 9,500) to sell at $12 \mathrm{X4,000}$ (or 48,000). On a tricycle load, our crusher earns 48,000 $-9,500=$ 39,500 , or about 40,000 FCFA. The proceeds from the sale of gravel are used for basic needs: food, clothing, care, schooling for children and even building a house. Rare are these actors who invest their income in the prevention of risks linked to their activities.

\section{Occupational risks associated with the artisanal crushing activity}

\subsection{Biomechanical risks}

Duration, effort, repetitiveness and postures are determining factors in the occurrence of musculoskeletal disorders. According to Ayoub and Wittels (1989) [9], physical stress can be expressed as the result of stresses in posture, strength, repetitiveness and various mechanical stresses. The artisanal crushing activity, as carried out in the Collines Department, is a source of biomechanical risks at all levels. The repetitiveness of the movements of physical forces exerted by massiers on very heavy mass hammers in the same posture for an average of 10 hours per day can generate tendonitis of the shoulder rotator cuff and tenosynovitis in the latter (Patry et al., 1998) [10] -. The repeated movements of the massiers can cause them musculoskeletal damage. Likewise, the constraining postures maintained for a prolonged period ( $10 \mathrm{~h}$ on average per day) of the massiers (photo 1.b of figure 7), the arms in elevation or in abduction, with repetitive handling of mass hammer weights on stone blocks constitute a risk factor in the development of musculoskeletal injuries in the neck, cervico-scapular region and in the appearance of tendon injuries in the shoulder, wrist and hand. The same risks are also observed for women and children who throughout the day remain in the same posture to crush stones. Repeated handling of the small hammers can generate carpal tunnel syndrome.

The prolonged exposure of crushing operators and surrounding populations to dust laden with mineral particles such as crystalline silicas can generate disabling chronic diseases (pneumoconiosis, cancer, etc.).

\subsection{Manifestation of the risks of the crushing activity at stakeholder level}

The results of surveys on the Behavior, Attitude and Perception (CAP) of the players in crushing on the risks of their activities made it possible to identify the discomforts felt by the latter. According to the actors met during the present study, artisanal stone crushing generates +++ noise, heat, manual vibrations, mineral dust, atmospheric pollution, falls, projectile wounds (photo a plate 4) lesions on the fingers (photo b plate 4) (the most exposed organs being the skin and eyes) and by the tools of work, landslide, exposure to the sun and other seasonal bad weather, snake and scorpion bites etc.

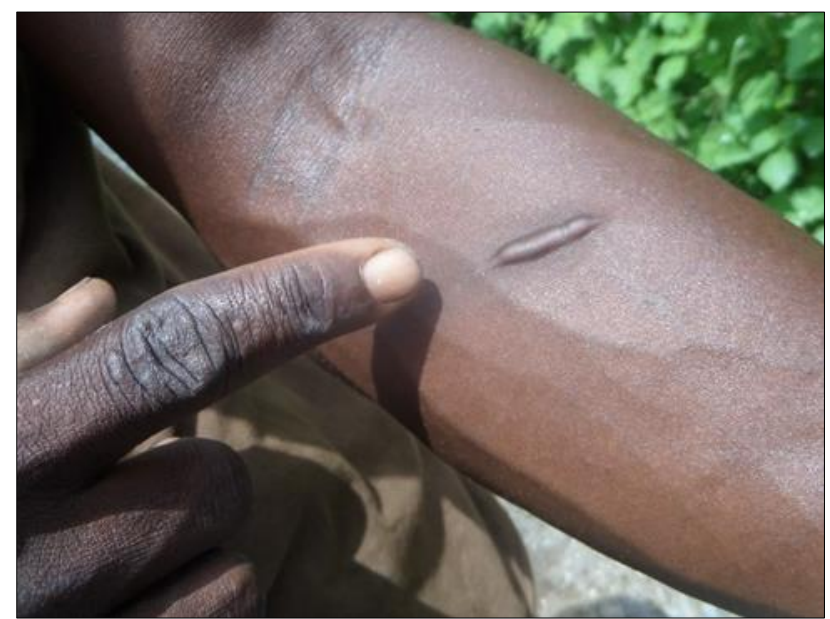

Photo 4 a Injury by projectiles

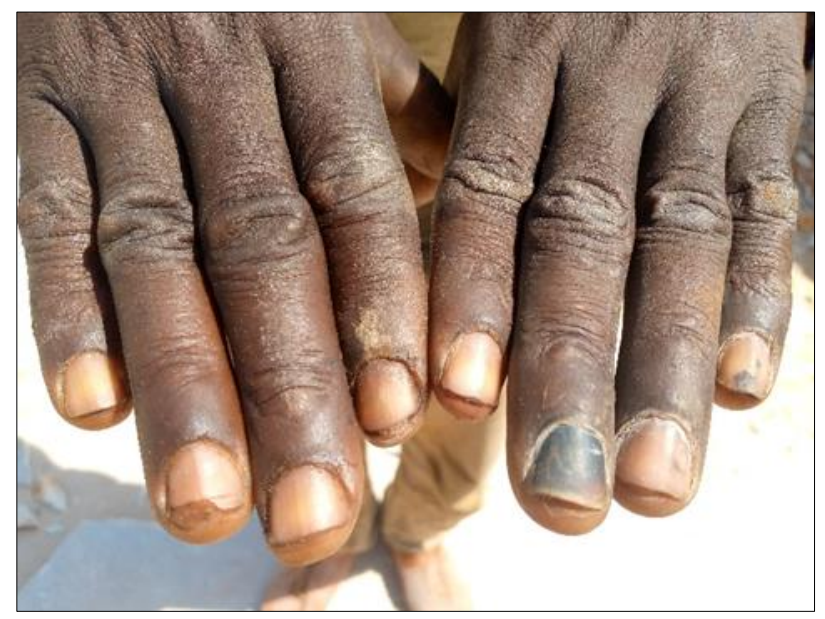

Photo 4 b Lesions in the fingers

Figure 7 Effects of the crushing activity on the actors; Shooting: TOSSOU F., 2020

Health complaints are dominated by fatigue, bone and joint pain, known as musculoskeletal disorders that predominate in the upper limbs and lower back, trauma, and cardio-respiratory problems. The major but fortunately rare risk is the landslide. The complaints identified with the crushing actors of the Collines Department are presented in Figure 8. 


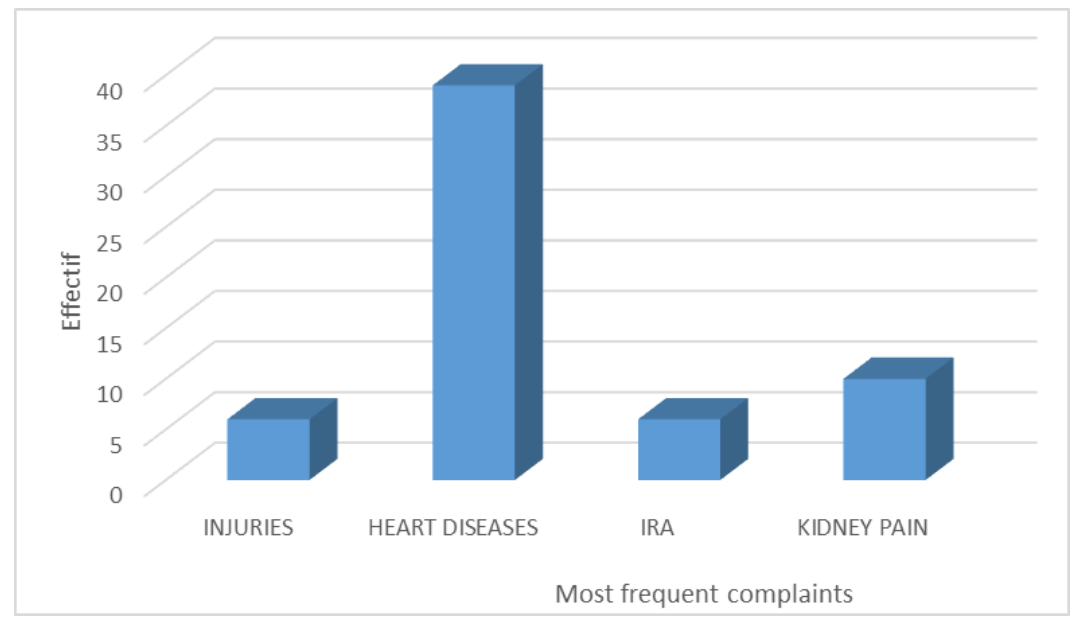

Figure 8 Breakdown of crushers according to working time per day; Source: Fieldwork, Tossou F., 2019

As shown in Figure 4, the complaints were: heartache (59.4\%), low back pain and back pain (12.3\%), followed by accidents $(9.4 \%)$ and respiratory ailments $(9.4 \%)$. For $4 / 5$, certain times of the year would be more at risk and for $45.3 \%$, it is the rainy season. More than $77 \%$ of people recognize that there are specific risks to children, including the risk of accidents.

\subsection{Environmental impact of the activity}

Granite crushing has significant effects on various components of the environment. On several crushing quarries studied, the woody species of the sites are the most felled as shown in photo a of figure 9.

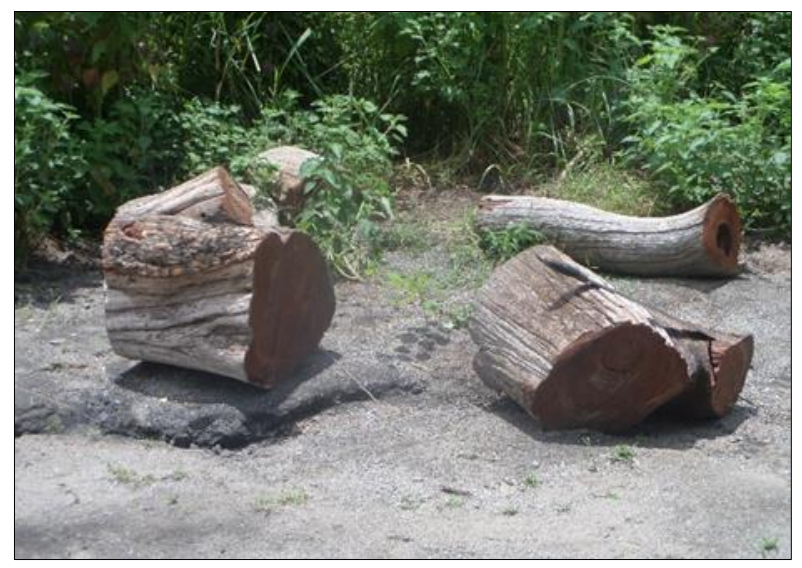

Photo a Cut woody species

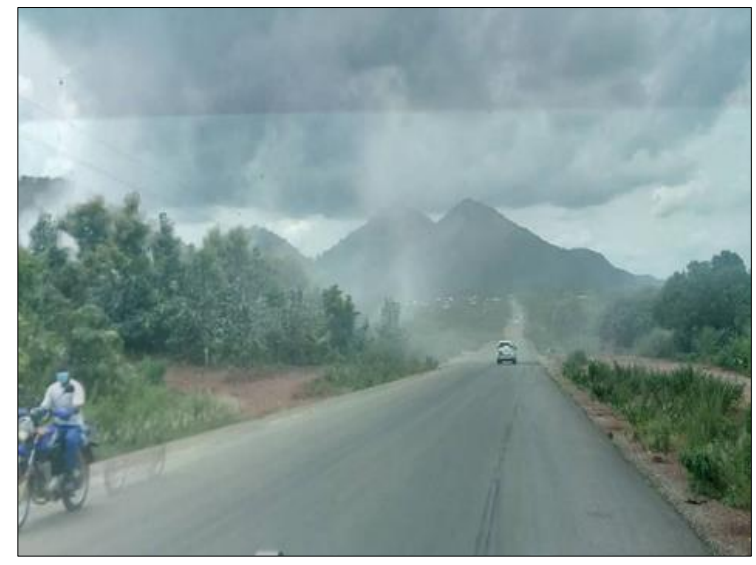

Photo $\mathbf{b}$ atmospheric pollution due to industrial

Figure 9 Effect of crushing activities on the environment: Shooting: TOSSOU F., 2020

The cut woody species serve as firewood for the pyro-diaclasage operation. Thus, important species are slaughtered. This gradually strips the hills and degrades the environment dangerously. The fumes produced by fuelwood added to the dust released by the crushing operation contribute to atmospheric pollution and reduce visibility on the roads, as shown in photo b of figure 9. Moreover, after extraction blocks of stones by the crushers, open pits are created and constitute receptacles of waste water, household refuse and breeding grounds. The populations living near these sites are therefore exposed to mosquito bites with its consequences and to other diseases linked to poor hygiene. Likewise, these holes are the causes of many cases of reckless accidents.

\subsection{Measures taken by those involved in crushing to prevent occupational risks}

Artisanal crushing is a dangerous activity which deserves adequate measures to limit the possible risks. This study looked at the measures taken by the players in this sector. In terms of careers, note that:

- Very few use protective measures. Even ordinary shoes are rarely worn, 
- The basic rules of hygiene are not respected: we eat in the workplace, sometimes without washing our hands; meals are not always protected,

- There are many children at the level of artisanal crushing

- The general population not engaged in this activity is exposed to dust and noise,

- There are awareness messages.

\section{Discussion}

Homemade stone crushing is a strenuous activity that requires a lot of muscle energy. In the Department of Hills, it constitutes an alternative activity to the present problems of agriculture. (Adjibogoun R., 2011) [11]shows that this activity can have enough strength and that its lack of organization totally dulls its value. The socio-demographic characteristics of crushers suggest that artisanal crushing is a profession for women, as have already been pointed out (Aballo, 2007) [12] and (Mongbo, 2007) [13]. The average age of crushers in the quarries mentioned in this study is 43 years and is lower than that found by (Aballo, 2007) [11] in Benin (Suarthana, 2008) [14] in Holland and (Gale, 1998) [15] in the region of Dan in Benign. The benefits of mining stone quarries are many and substantial. The natural and legal persons who operate this operation are doing well. Even in the informal sector, incomes are quite high and allow the satisfaction of basic needs such as food, care, clothing, schooling for children and even house building. The State carries out quality works: dikes, buildings, bridges and roadways with crushed stones. Which demonstrates its usefulness. But this activity presents enough professional risks (Toussou et al. 2021) [7]. The health cost, represented by professional risks, injuries and illnesses as well as the costs of medico-pharmaceutical care, are also high. Here, the measurement is difficult, because we can witness disabling chronic diseases (pneumoconiosis, cancers) and even loss of human life.

The other very big cost is environmental pollution. Mineral dust and certain toxic gases pollute the air and plant cover, even endangering certain populations not professionally exposed. A mission to assess working conditions in the careers of formal companies carried out a few years ago by the Department of Occupational Health found similar risk factors:

- mineral dust (especially during drilling and granite crushing operations),

- noise: impact noise from the detonation of dynamites (during firing) and the continuous noise of crushers and perforators (exceeding $109 \mathrm{~dB}$ ),

- vibrations due to jolting machines (such as the perforator and the crawler excavator) and the many construction trucks,

- the landslide when the dynamited rocks collapse well after the shot,

- the drop in leveling in the event of a high forassion operation (through inattention, the worker tumbles into the excavations),

- exposure to sun and rain,

- gas inhalation (nitroglycerin), skin irritation on contact with gas

- projectile wounds during firing,

- $\quad$ snake bites.

The mission noted that there was virtually no medical follow-up (no hiring medical examinations and no periodic medical examinations).

Crystalline silica is a still current occupational risk, linked to many pathologies, of which silicosis remains the most frequent (Borges, 2002; Pallady Jacob, 2009) [16, 17]. Thus, (Calvert GM, 2003) [5] have found the already known associations between occupational exposure to silica and Chronic Obstructive Pulmonary Disease (COPD), pulmonary tuberculosis and bronchopulmonary cancer (PBC), and provide arguments in favor of a relationship between this exposure and rheumatoid arthritis. Likewise, (Brodo, 2002) [18] have shown that acute exposure to silica in mice induces active apoptosis of CD4 $+\mathrm{T}$ lymphocytes in silica-draining lymph nodes and in inflammatory pulmonary granulomas. Therefore, active apoptosis induced by silica may have an important role in inflammation and cause immunological disorders in regional lymph nodes draining silica. This result justifies the high frequency of unstable chromosomal aberrations, in particular the dicentrics observed in rock crushers in this study. In addition, a differential diagnosis is opportune to identify other genotoxic factors other than silica.

\section{Conclusion}

The exploitation of stone quarries in Benin, even in the informal sector, has interesting economic and social advantages, in the sense that it provides significant purchasing power. Most people who engage in it find that the activity allows 
them self-realization through satisfied needs. The health and environmental problems associated with the exploitation of stone quarries are numerous, but few preventive measures are taken, whether it be technical prevention or medical prevention.

The benefit-cost ratio of the activity could be very interesting if health, safety and environmental protection measures are effectively taken in all industrial and artisanal quarries.

\section{Compliance with ethical standards}

\section{Acknowledgments}

We thank everyone who contributed to the writing of this manuscript. We particularly thank the actors of artisanal stone crushing of the Department of Hills for accepting to answer our questions and who helped us to have a lot of information on the crushing activity.

\section{Disclosure of conflict of interest}

The writing of this manuscript is without conflict of interest. Each of the authors contributed to the success of this manuscript.

\section{Statement of informed consent}

All actors who contributed to this study gave their consent and agreed to participate in this research

\section{References}

[1] Jennings NS. Mines and quarries: a general overview of the extractive industries (ed. 3rd edition). International Labor Office. 2014; 88.

[2] Keita S. Study on artisanal mines and small-scale mining in Mali. Mining, Minerals and Sustainable Development. 2001; 96.

[3] Bonnetain B. Project study to help the stone breakers of Cobly (Benin). REES 19, ASF/MFR, 35.2013.

[4] Department of Health. Exposure to dust during work. State of Luxembourg. Brochure. 2005; 16.

[5] Calvert GM. Occupational silica exposure and risk of various diseases: analysis using death certificates from 27 states in the United States. Occup Environ Médicine. 2003; 60: 122-129.

[6] Tossou Félicien, Yabi Ibouraima, Landeou C. Rodrigue, Boko Michel. Caracterization of the artisanal stone crushing activity in the informal sector in the collines department in Benin. International Journal of Sciences Academic Researchh. 2021; 02(04): 1338-1343.

[7] Landeou Codjo Rodrigue ; Sominanhouin André ; Avocefohoun Alphonse ; Houssou Sègbè Christophe ; Akogbeto Martin. Analysis of the spatio-temporal distribution of larvae of culicidae vectors of diseases in the Dassa-Glazoue health zone. Spatial Dynamics and Development: Bi-annual review of the Urban and Regional Dynamics Studies Laboratory. 2018 : 123-143

[8] Tossou L Félicien. Assessment of working conditions in traditional sub-Saharan agriculture: pilot study among cotton producers in southern Benin. DES thesis in occupational health, ergonomics orientation. Medical School. Catholic University of Louvain (UCL) Bruxelles. 2001; 113.

[9] Ayoub MA, Wittels NE. Cumulatives trauma desorders. international Review of Ergonomics. 1989; $217-272$.

[10] Patry Louis, Rossignol Michel, Costa Marie-Jeanne, Baillargeon Martine. Guide for the diagnosis of musculoskeletal injuries attributable to repetitive strain. Quebec research institute in occupational health and safety. 1998; 43.

[11] Adjibogoun R. Diagnostic study of the artisanal stone crushing activity in rural areas: case of the municipality of Dassa-Zoumè Master thesis University of Abomey-Calavi 2011.

[12] Aballo S. Radiographic aspects of the pulmonary pattern in stone breakers from Tchatchegou to Glazoue (Benin). Master's thesis. University of Abomey-Calavi EPAC. 2007; 81. 2011; 115 
[13] . Mongbo SJ. Through granite, work represses the future of Beninese children. Periodical of the NGO SIN -DO, Numéro. 2007; 10.

[14] Suarthana E. A simple diagnostic model for ruling out pneumoconiosis among construction workers. Occup Environ Med. 2008; 64(9): 595-601.

[15] Gale TM. Systematic radiographic examinations among workers in the Dan quarry in Benin: place of silicosis. Thesis Polytechnic University College / National University of Benin. 1998; 91.

[16] Borges VMJ. Fundamental role of apoptosis in the immunopathogenic mechanisms of acute silicosis. . Amer J Respir Cell Molec Biol. 2002; 27(1): 78-84.

[17] Pallady Jacob C. Exposure to silica in heavy vehicle drivers: a new occupational risk? About two cases. Thesis by Marte University of Nantes. 2009; 114.

[18] Brodo MS. Silica, hyaluronic acid and functional differentiation of alveolar macrophages.. Amer J Respir. Cell Molec Biol. 2002; 27(1): 78-84. 